\title{
APLIKASI SEGMENTASI PARU - PARU
}

\author{
Amin Hariyadi, Linda Salma Angreani, A.Syahirul Fatkhurrahman \\ Teknik Informatika UIN Maulana Malik Ibrahim Malang
}

\begin{abstract}
Abstrak-Paru-paru merupakan salah satu organ tubuh penting dalam tubuh manusia. Karena paru-paru merupakan salah satu pemegang kendali dalam sistem peredaran udara dalam tubuh manusia. Maka dari itu pendeteksian terhadap gangguan pernapasan manusia sangat dibutuhkan. Pada citra $x$-ray thorax terdapat informasi yang digunakan untuk menganalisa dan mengetahui bentuk suatu objek dari paru-paru itu sendiri. Untuk memperoleh informasi tersebut, perlu melakukan proses segmentasi. Dalam penelitian ini menggunakan metode Chan-vese. Metode Chan-vese merupakan region based model perbaikan dari edge based model. Tujuan penelitian ini untuk mengimplementasikan segmentasi paru-paru pada citra x-ray thorax dengan menggunakan metode Chan-vese untuk mencari nilai validitas. Hasil segmentasi paru-paru tersebut dilakukan uji coba sistem yang dilakukan pada 20 data citra $x$-ray thorax didapatkan rata-rata hasil akurasi $87.89 \%$, sensitifitas $76.27 \%$ dan spesifisitas $93.97 \%$. Nilai akurasi tertinggi sebesar 92.0502, dan terendah sebesar 82.0419. Nilai sensitifitas tertinggi sebesar 83.1183, dan terendah sebesar 68.3135. Nilai spesifisitas tertinggi sebesar 98.706, dan terendah sebesar 88.3848 .
\end{abstract}

\section{PENDAHULUAN}

Tubuh manusia terdiri dari susunan tulang dan organ tubuh lainnya yang menopang kelangsungan proses metabolisme dalam tubuh. Diantaranya organ-organ penting diantaranya tulang, jantung, paru-paru, dan hati. Pada bagian atas, tulang berguna dalam melindungi bagian dalam tubuh, misalnya paru-paru. Paru-paru merupakan organ tubuh yang memegang kendali sistem peredaran udara atau oksigen. Paru-paru sendiri berfungsi sebagai penukar oksigen dari udara dengan karbon dioksida dari darah, prosesnya disebut dengan pernapasan eksternal, atau bisa disebut dengan bernapas. Dalam sistem ekskresi, paru-paru mengeluarkan karbondioksida(Co2) dan uap air(H2O). Karbondioksida dan uap air dilepaskan dan dikeluarkan dari paru-paru melalui hidung. Meskipun bisa mendapatkan oksigen dengan kualitas yang baik, tapi jika fungsi paru-paru sedang mengalami gangguan, hal tersebut menjadi tidak berguna, karena media transmisinya tidak bekerja dengan baik.

Menurut beberapa dokter ahli penyakit dalam, paru-paru merupakan organ dalam yang paling rawan mengalami kerusakan, hal ini disebabkan fungsi paru-paru yang bersentuhan secara langsung dengan lingkungan luar, karena paru-paru berfungsi mengambil udara dari luar tubuh

(lingkungan). Oleh sebab itu diperlukan pemeriksaan yang lebih teliti dari setiap perubahan pada organ-organ yang ada di rongga dada, terutama paru-paru (Waugh, 2004).

Organ paru-paru dan jantung keduanya memiliki keterkaitan yang cukup signifikan, jika salah satu mengalami masalah atau gangguan maka akan berdampak pada organ yang lain, secara umum paru-paru sering menjadi pemicu awal terjadinya gangguan. Perlu diwaspadai dan diketahui bahwa penyakit jantung adalah pembunuh yang paling berbahaya saat ini, penderitanya tidak mengenal strata ekonomi, bisa berasal dari kalangan ekonomi tinggi sampai orang dari kalangan ekonomi lemah. Salah satu tanda penyakit ini adalah adanya pembesaran ukuran jantung yang dikenal dalam istilah medis "cardiomegaly"(Inoue, 1999). Secara umum apabila terjadi pembengkakan ukuran jantung, maka hampir bisa dipastikan ada indikasi mempunyai penyakit jantung.

Pemantauan pembesaran jantung selama ini masih menggunakan modaliti $X$-ray, karena modaliti ini hampir tersedia hampir di seluruh rumah sakit, bahkan banyak 
puskesmas yang sudah mempunyai peralatan ini (Depkes RI, 2007). Guna mengetahui adanya kelainan organ-organ pada rongga dada dari hasil citra $X$-ray thorax diperlukan analisis dan interpretasi yang akurat, oleh karena itudiperlukan suatu keahlian khusus yaitu ahliradiologi (radiolog). Sedangkan ahli radiologi di Indonesia jumlahnya masih cukup terbatas, apalagi yang memiliki sertifikat bertaraf internasional.

Salah satu metode yang digunakan oleh ahli radiologi dalam menentukan adanya cardiomegaly, dengan menghitung rasio antara nilai maksimum transverse diameter dari jantung dibandingkan dengan nilai maksimum transverse diameter dari rongga dada. Nilai rasio ini dikenal dengan cardiothoracic ratio (Bram, 2002).

Perhitungan cardiothoracic ratio(CTR) sudah diterima dan digunakan oleh kalangan medis, tidak hanya sebagai metode yang cukup mudah akan tetapi nilainya dapat digunakan sebagai parameter klinis tentang jantung. Pada orang dewasa, nilai CTR diatas $50 \%$ mengindikasikan terjadinya pembesaran jantung, sedangkan pada bayi yang baru lahir nilai CTR66\% adalah nilai batas normal (Artawijaya, 2010).

Cardiothoracic ratio sangat berguna dan cukup valid untuk mendeteksi adanya gangguan jantung, terutama yang ditandai dengan adanya pembesaran ukuran jantung (cardiomegaly).Gannguanjantung lebih dari lima puluh prosen $(50 \%)$ ditandai dengan adanya cardiomegaly, diantaranya (Arnold, 2005):

1. Kegagalan jantung (cardiac failure)

2. Pericardial effusion

3. Left or right ventricular

4. hypertrophy.
II. PEMBAHASAN.

A. Model

Pembuatan perangkat lunak menggunakanmodel Waterfall, yang terdiri dari tahapan sebagai berikut :

1. Rekayasa Sistem

Tahap ini merupakan kegiatan pengumpulan data sebagai pendukung pembangunan system, menentukan ke arah mana aplikasi ini akan dibangun.

2. Analisis Sistem

3. Perancangan Sistem

4. Pengkodean Sistem

5. Pengujian Sistem

6. Pemeliharaan Sistem

7. Umpan Balik
B. Analisis Segmentasi Paru-Paru

Langkah-langkah dalam melakukan segmentasi paru - paru sebagai berikut :

Input citra asli (foto thorax PA).

1. Pre-Processing.

2. Inisialisasi kontur.

3. Menentukan Narrow band.

4. Perhitungan interiorpoint (C1) dan exteriorpoint (C2).

5. Perhitungan pergerakan kontur pada narrowband.

6. Inisialisasi ulang kontur untuk iterasi berikutnya.

7. Langkah 3-7 diulang sampai iterasi $>$ optimum.

C. Desain

Desain tahapan proses segmentasi paru-paru digambarkan pada gambar 1 dibawah ini :

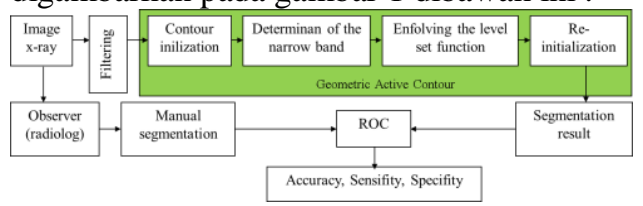

Gambar 1. Tahapan Proses Segmentasi Paru-paru

Untuk Desain antar muka aplikasi seperti pada gambar 2,3, dibawah ini.

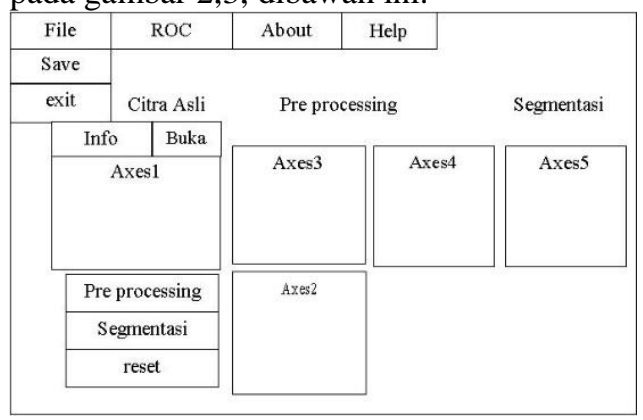

Gambar 2 Desain antar muka menu utama

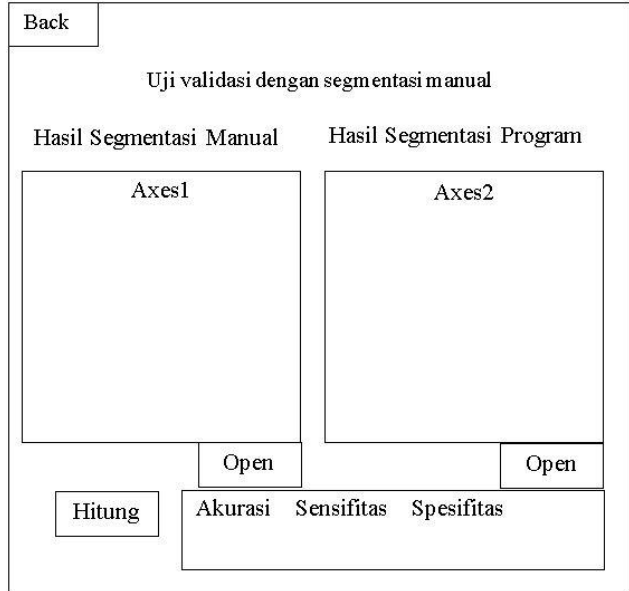

Gambar 3 Rancangan Menu ROC 


\section{IMPLEMENTASI}

Berikut implementasi antarmukaaplikasi segmentasi paru-paru

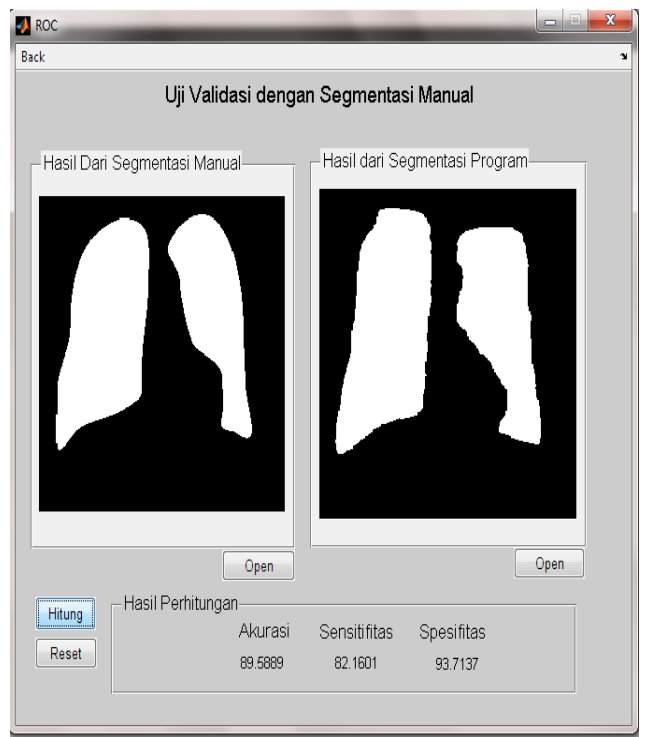

Gambar 4. Aplikasi Segmentasi Paru-paru

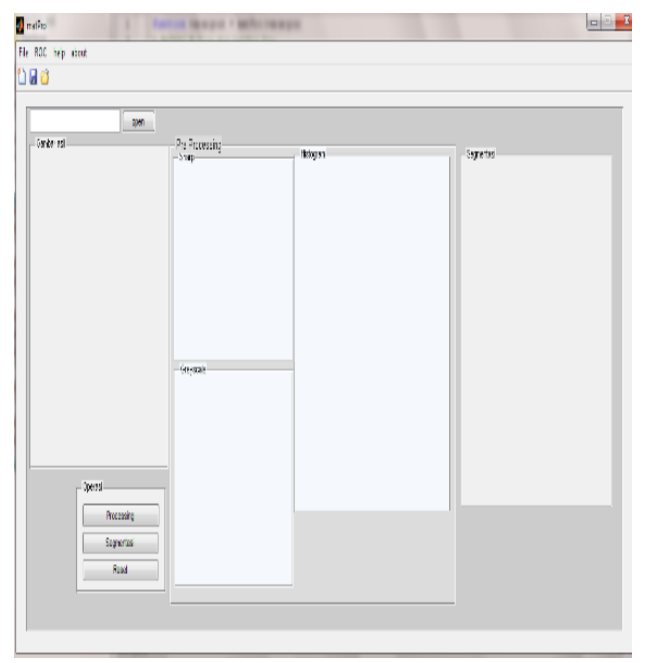

Gambar 5.Antar Muka Uji Validasi

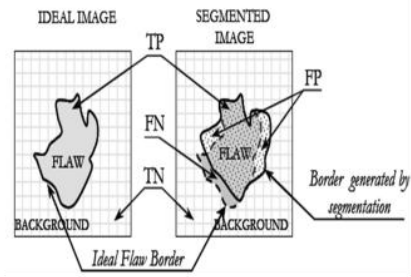

Formulasi matrix dari TP,TN,FP,FN

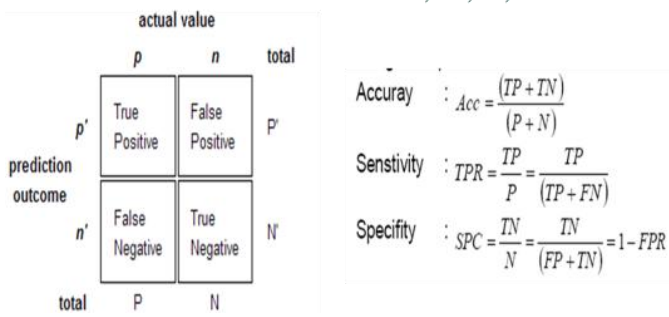

Gambar 6. Perhitungan Proses Pengujian

Tabel1. Hasil Pengujian

\begin{tabular}{|l|l|l|l|l|}
\hline No & $\begin{array}{l}\text { Nama } \\
\text { citra }\end{array}$ & $\begin{array}{l}\text { Akurasi } \\
\mathbf{( \% )}\end{array}$ & $\begin{array}{l}\text { Sensitifitas } \\
\mathbf{( \% )}\end{array}$ & $\begin{array}{l}\text { Spesifitas } \\
\mathbf{( \% )}\end{array}$ \\
\hline 1. & JPCLN001 & 84.79 & 74.467 & 90.798 \\
\hline 2. & JPCLN007 & 82.0419 & 71.7594 & 88.3848 \\
\hline 3. & JPCLN008 & 89.9994 & 83.1183 & 94.6941 \\
\hline 4. & JPCLN018 & 85.434 & 76.4803 & 94.6184 \\
\hline 5. & JPCLN021 & 85.7788 & 77.3601 & 90.8752 \\
\hline 6. & JPCLN023 & 89.6744 & 79.978 & 94.811 \\
\hline 7. & JPCLN035 & 88.1348 & 82.1828 & 91.9457 \\
\hline 8. & JPCLN043 & 91.0446 & 81.3049 & 95.3703 \\
\hline 9. & JPCLN045 & 87.2635 & 82.5478 & 90.3754 \\
\hline 10. & JPCLN049 & 86.4502 & 81.098 & 89.7336 \\
\hline 11. & JPCLN005 & 82.6416 & 70.0436 & 88.7165 \\
\hline 12. & JPCLN009 & 84.0317 & 71.0723 & 91.2765 \\
\hline 13. & JPCLN024 & 91.9586 & 76.2709 & 98.706 \\
\hline 14. & JPCLN025 & 90.6128 & 76.0845 & 96.3913 \\
\hline 15. & JPCLN030 & 86.937 & 72.4075 & 93.8869 \\
\hline 16. & JPCLN031 & 91.156 & 78.15 & 97.5549 \\
\hline 17. & JPCLN033 & 90.5411 & 74.1934 & 97.894 \\
\hline 18. & JPCLN038 & 92.0502 & 79.0569 & 97.1579 \\
\hline 19. & JPCLN039 & 89.3295 & 69.5834 & 98.225 \\
\hline 20. & JPCLN062 & 88.0905 & 68.3135 & 98.1688 \\
\hline Rata-rata & 87.89 & 76.27 & 93.97 \\
\hline
\end{tabular}

\section{PENGUJIAN SISTEM.}

Pengujian segmentasi citra objek tunggal ini menggunakan standar pengukuran kesalahan atau error, dan di dalam pengujian ini menggunakan Mean Square Error (MSE).

MSE merupakan pengukuran yang baik untuk mengukur kesamaan dua citra, misalnya ada buah citra $x$ dan $y$ dengan dimensi yang sama sebesar $\mathrm{MxN}$ dan penghitungan MSE antar kedua citra dapat didefinisikan dengan persamaan sebagai berikut:

$M S E=\frac{1}{M x N} \sum_{i=1}^{M}+\sum_{j=1}^{N}\left(x_{i j}-y_{i j}\right)^{2}$ 
Proses PengujianAplikasi Segmentasi Paru-paru menggunakan nilai TP, TN, FP dan FN untuk mendapatkan nilai dari akurasi, sensitifitas dan seperti pada gambar 6.

Hasil pengujian sistem terdapat pada tabel 1 dibawah ini.

\section{KESIMPULAN DAN SARAN}

\section{A. Kesimpulan}

Segmentasi Bentuk Paru-Paru Pada Media X-Ray Thorax Dengan Metode CV(ChanVese) dapat ditarik kesimpulan sebagai berikut yaitu,

1. Metode chan-vese dapat digunakan untuk mensegmentasi objek paru-paru rata-rata hasil akurasi $87.89 \%$, sensitifitas $76.27 \%$ dan spesifisitas 93.97\%.

2. Hasil akurasi minimum, pada gambar JPCLN007 dengan akurasi 82.0419 dan akurasi maximum pada gambar JPCLN038 dengan akurasi 92.0502, hasil sensitifitas minimum, pada gambar JPCLN062 dengan sensitifitas 68.3135 dan maximum pada gambar JPCLN008 dengan sensitifitas 83.1183, hasil spesifitas minimum pada gambar JPCLN007 dengan spesifitas 88.3848 dan spesifitas maximum pada gambar JPCLN024 dengan spesifitas 98.706.

\section{B. Saran}

Program ini masih memiliki banyak kekurangan sehingga dapat digunakan menjadi acuan dalam pengembangan penelitian di masa yang akan datang. Terdapat beberapa saran untuk program ini yaitu,

1. Program masih terbatas dalam hal segmentasi saja, proses preprocessingdalam hal ini sangat menentukan untuk memperoleh hasil segmentasi yang bagus.

2. Inisialisasi awal diletakkan pada posisi yang paling dekat dengan tepian objekyang akan di segmentasi yaitu bagian dalam objek. Apabila diletakkan diluar objek, maka kontur akan medeteksi keseluruh bagian citra dada.

\section{DAFTAR PUSTAKA}

[1] Ch, Marvin, Agus.P. 2007. Pengolahan Citra Digital menggunakan Matlab.Penerbit Informatika. Bandung

[2] Hariyadi, Amin 2014,Pengukuran Semi-Otomatis Cardio Thoracic Ratio (CTR) menggunakan Geometri Kontur Aktif, Disertasi, Program Doktor Jurusan Teknik Elektro Fakultas Teknologi Indutri Institut Teknologi Sepuluh Nopember Surabaya

[3] Lailyana, Eviv. 2009. Segmentasi Citra Medis Paru-paru Pada Citra Xray Menggunakan Level Set. Jurusan Teknik Elektro Institut Teknologi Sepuluh November.

[4] Mardiyah, Ainatul. 2012. Metode Segmentasi Paru-Paru Dan Jantung Pada Citra X-Ray Thorax. Tesis. Jurusan Program Studi S2 Ilmu Komputer, Fakultas Matematika Dan Ilmu Pengetahuan Alam, Universitas Gadjah Mada. Yogyakarta.

[5] Wijaya, Marvin Ch, \& Agus Prijono.2007. Pengolahan Citra Digital Menggunakan Matlab Image Processing Toolbox. Bandung: Informatika. 